\title{
The Effect of Understanding the Role and Position of State Civil Apparatus Agenda on Work Behavior of Basic Training Participants of Candidates for Civil Servants
}

\author{
Ade Suhendar*, Asep Suryana \\ Educational Administration Department, School of Postgraduate Studies \\ Universitas Pendidikan Indonesia \\ Bandung, Indonesia \\ *adsuhendar99@upi.edu
}

\begin{abstract}
The success or failure in one's professional life is influenced by many factors that are closely related in daily life or profession. The State Civil Apparatus has duties and functions that are regulated in law so that in living their life while acting as a state servant begins with their role as a public servant, so that their professional behavior in their work environment is influenced by the values built in themselves and their organizations. Basic Training for Candidates for Civil Servants expected to be able to instill the basic values of State civil apparatus and the role of State civil apparatus's position to be used as a basis and guidelines as well as a reference in daily work actions and behavior. This study aims to determine the influence of the agenda of understanding the role and position of State civil apparatus on the work behavior of basic training for Candidates for Civil Servants graduates. The research method used is a quantitative method. The population in this study were all basic training for Candidates for Civil Servants participants who took part in basic training activities at the PUSLATBANG PKASN (Pusat Pelatihan dan Pengenbangan dan Pemetaan Kompetensi Aparatur Sipil Negara) Training Center in 2019, amounting to 280 people, while the number of samples used was 76 people. Based on the Chi Square Test the which has been Carried out at a significance level of $10 \%$, the result is that $\chi 2$ count $=11145$ is greater than $\chi^{2}$ table $=7.78$, Thus $H 0$ states that there is no significant influence between understanding the role agenda and the position of civil servants on graduates work behavior. Civil Servants basic training was rejected. This means that understanding the role and position of civil servants agenda has changed the work behavior of candidate of civil servants basic training graduates.
\end{abstract}

Keywords-mindset, training, role and position of state civil apparatus

\section{INTRODUCTION}

The world is now entering an era where digital economy, artificial intelligence, big data, robotics are becoming a necessity. The development of increasingly sophisticated technology has significantly changed human life and work This gave birth to the phenomenon of disruptive innovation occurring in all aspects of life. This era is known as the era of the industrial revolution 4.0.

In the next five years, the 4.0 industrial revolution will wipe out at least 35 percent of jobs. Even the prediction in the next ten years, the industrial revolution 4.0 will eliminate as many as 75 percent of jobs. The work in which the main actors are played by humans, will gradually be replaced by machines through its digitalization technology. If addressed positively, this disruptive phenomenon will certainly greatly assist local governments in improving services to their citizens.

Facing these challenges, civil servants as public servants with an important role in the process of public service in the community, the state assets that need to develop right potential and ability. To make this happen, it is necessary to design an appropriate training for candidate for civil servants as the beginning of character building and competence according to the demands of their position.

Based on existing theory, thought (mindset) greatly determined action / behavior. This means that the success or failure of a person in the course of his life is dominantly influenced and determined by a person's way of thinking. In this regard, for a candidate of civil servants who will start his work in the world of public service, his work behavior is influenced by the values built in him so that he will be able to realize the role and position of State civil apparatus in his work. Before entering the world of complete state civil apparatus, a civil servant must go through the stages of education and training, known as the Basic Training for Candidates for Civil Servants are expected to understand the role and position of the State civil apparatus to be a provision in the actions and behavior of daily work. For this reason, this study was conducted to determine the effect of understanding 
the role and position of State civil apparatus on the work behavior of candidate civil servants Basic training graduates.

\section{LITERATURE REVIEW}

\section{A. Mindset, Attitude, and Behavior}

One of the most basic things that can distinguish a person's ability to think is their mindset (mindset). Mindset is at the core of the human mind where the brain functions as a decision maker regarding whether an input is accepted or rejected. After the information is received, the final decision regarding whether or not the information is received is determined by a person's mindset [1]. The better a person's thinking ability, the better he will act.

A mindset is also defined as a set of thoughts that are strengthened by beliefs and projections to become reality [2]. Mindset is also interpreted as a person's mental position or outlook that influences the person's approach in dealing with a phenomenon. Mindset is also defined as a belief that affects a person's attitude, a set of beliefs or a way of thinking that determines a person's behavior and views, attitudes and future [3]. The mindset is actually more similar to a belief or doctrine that is embedded in the brain and is heavily influenced by the environment [2].

In its development, creativity is needed in developing a mindset. This happens because it takes strength to hone energy and thoughts into something useful [4]. A person who has a strong energy to move forward towards success and has clarity in his personality, tends to take advantage of opportunities to achieve his goals [5]. Human certainly different in many ways, such as talent, early ability, interest or temperament. S ach person can change and evolve through the treatment and experience it. The characteristics of people whose mindset is developing are having the belief that intelligence, talents, and traits are not hereditary functions, learning to accept challenges and being serious in carrying them out [6].

Based on various definitions of mindset, it can be concluded that the mindset is a person's way of thinking and beliefs that affect each person's attitude and behavior which ultimately determines one's future and life success level. A person's mindset greatly influences one's actions and destiny, meaning that one's success or failure in the course of life is dominantly influenced and determined by one's thinking. So if you want to be successful, someone who has the ability to think is required to be able to use and actualize his way of thinking optimally, and he is required to be able to change the way of thinking in accordance with the demands of space and time being faced.

\section{B. Attitudes and Behaviors}

Attitude can be defined as an affective tendency to like or dislike a certain social object. Attitude is also defined as an expression of one's affection on certain social objects which have a possible range of likes to dislikes. These social objects can vary, maybe people, maybe people's behavior, maybe social institutions, or other things [7]. When viewed based on the constituent elements, attitudes can be divided into three things, namely transformative, transactive, and transinternal attitudes. A transformative attitude is an attitude that is more psychomotor or less aware. Transactional attitude is an attitude that is more fundamental to objective reality. Meanwhile, a transinternal attitude is an attitude based on life values.

Judging from the attitude category, a person's attitude towards a certain object can be influenced by the values adopted or the background for that person as his life experience. People already have certain values in their mental and personality, of course they can face and respond to those things which are colored by the values they believe in. Attitude is usually associated with behavior. Behavior is a manifestation of a person's response or reaction to certain social environmental stimuli.

Attitudes can be learned through observation, hearing and experience. In other words, attitude is an act and self-behavior based on the way of thinking of an individual [8].

Behavior is included in the psychomotor domain as well as skill performance. Skills relate to aspects of the speed, accuracy, and stability of a response or reaction to an environmental stimulation. Some of the skills related to a person's success in life include empathy skills (skills related to social behavior), intellectual skills, mental skills (mental resilience or toughness), skills in managing desires and motivation, and skills in behaving accordingly. community ethics (good and bad character).

\section{LAN Regulatory Policy No. 12 of 2018 Concerning Basic training Candidate for Civil Servants}

Candidate for civil servants Basic Training based on State Administration Institution Regulation No. 12/2018 aims to develop the competence of candidate for civil servants which is carried out in an integrated manner [9]. Competence is measured based on four aspects. First, the attitude of defending the country. Second, actualization of the basic values of civil servants in carrying out their duties. Third, actualizing the position and role of civil servants within the framework of the Republic of Indonesia. Fourth, mastery of the required technical competencies in accordance with the field of work.

In relation to the structure of the candidate for civil servants basic training curriculum, the candidate for civil servants Basic training curriculum consists of a civil servant character building curriculum, and a curriculum for strengthening technical competences in their field of duty. The curriculum for the formation of civil servant characters consists of an agenda for state defense behavior, an agenda for basic values of civil servants, an agenda for the position and role of civil servants in the Republic of Indonesia, and an agenda for habituation. Meanwhile, the curriculum for strengthening technical competencies in the field of duty emphasizes competency development practices in order to support the implementation of duties and positions, which consists of administrative technical competence and substantive technical competence. 
First, the agenda for state defense behavior equips Basic training candidate for civil servants participants with an understanding of national insight through the meaning of the values of state defense, so that participants have the ability to demonstrate attitudes of state defense behavior in a preparedness that reflects physically and mentally healthy facing contemporary issues in carrying out their duties. as a professional civil servant public servant. The training course in the attitude of state defense behavior includes insight into the nationality and values of state defense, analysis of contemporary issues, and preparedness to defend the state.

The training course on national insight and state defense values, analysis of contemporary issues, and state defense preparedness equips participants with the ability to understand national insight through interpreting the values of state defense, so that participants have the ability to demonstrate attitudes to state defense behavior in a preparedness that reflects Physically and mentally healthy faces contemporary issues in carrying out their duties as a professional civil servant in community service through learning that focuses on practical learning.

Second, the state civil apparatus basic values agenda equips participants with the basic values needed in carrying out civil servant duties professionally as public servants which include the ability to be accountable, prioritizing national interests, upholding public ethical standards, innovating to improve the quality of the implementation of their duties, as well as not corruption and encouraging the acceleration of corruption eradication within the institution. The training course for learning the basic values of civil servants includes accountability, nationalism, public ethics, quality commitment, and anti-corruption. These five courses are often abbreviated as ANEKA (Akuntabilitas, Nasionalisme, Etika, Komitmen mutu and Anti Korupsi).

Eyes Accountability training to facilitate the formation $n$ use values basic values of accountability on Basic training Participants employees through learning substance associated with the basic values of accountability, conflict of interest in the public, civil servants neutrality, fairness in public service and consistent attitudes and behavior. The Nationalism training course facilitates the formation of the value of Pancasila in fostering state apparatus nationalism as the implementer of public policy, public service, and as the glue and unifier of the nation. The Public Ethics course facilitates the formation of basic values of public ethics in training participants through learning the code of ethics and behavior of public officials, the forms of the code of ethics and their implications, and the application of the civil servant code of ethics. Furthermore, the Quality Commitment course facilitates the formation of innovative basic values and quality commitment to training participants, through learning about the effectiveness, efficiency, innovation and quality of government administration, and the consequences of change, while the Anti-Corruption training course facilitates the formation of basic anti-corruption values in training participants through anti-corruption awareness learning, avoiding corrupt behavior, building an integrity system, and the process of internalizing anti-corruption core values.

Third, the agenda of the position and role of civil servants in the Republic of Indonesia equips participants with knowledge about the position and role of civil servants to carry out the functions of state civil apparatus as implementers of public policy, public servants, and the glue and unity of the nation so that they are able to manage challenges and problems of socio-cultural diversity using the Whole Government in supporting the implementation of their duties. The training course for the position and role of civil servants in the Republic of Indonesia includes state civil apparatus management, public services, and the Whole of Government.

The state civil apparatus management training course provides training participants with knowledge of the position, roles, rights and obligations, and code of ethics of state civil apparatus, the concept of the merit system in managing state civil apparatus, and state civil apparatus management, the mindset of civil servants as public services, practice of public service etiquette. The public service training course equips participants with the ability to provide quality public services through the concepts and principles of public service, the mindset of civil servants as public servants, as well as the practice of public service etiquette. The Whole of Government training course equips participants with knowledge about integrated government management systems in the delivery of services through learning the concept of Whole of Government, its application, and best practices for implementing Whole of Government in integrated service delivery.

Fourth, the habituation agenda facilitates participants to carry out the actualization process through familiarizing themselves with the competencies that have been obtained through the various courses that have been studied. The course of training for the habituation agenda includes conceptualization of actualization, explanation of actualization, design and guidance of actualization, evaluation of actualization design, provision of habituation, actualization in the workplace, preparation of actualization evaluation, and evaluation of actualization.

In the candidate for civil servants Basic training, there is an evaluation stage that is carried out to assess the achievement of character building for candidate for civil servants Basic training participants. The assessment aspects of the participant evaluation consist of evaluating behavioral attitudes, academic evaluations, and actualization evaluations. The evaluation qualifications consist of five categories, namely very satisfying (with a score of 90.01 - 100); satisfactory (with a score of 80.01 -90.0); quite satisfactory (with a score of $70.01-80.0$ ); less satisfactory (with a score of 60.01 - 70.0); and unsatisfactory (with a score below 80.0). Candidate for civil servants Basic training participants are declared to have passed if they get the lowest qualification which is satisfactory enough for every aspect of the participant evaluation assessment. Candidate for civil servants Basic training Participants are declared to have their graduation postponed if they get 
unsatisfactory qualifications, while Candidate for civil servants Basic training Participants are declared not to pass if they get unsatisfactory qualifications or the number of absent participants is more than what has been determined.

\section{RESEARCH METHODS}

This research is a descriptive study with a quantitative approach. The mindset reflected through understanding the role and position of candidate for civil servants is actually not easily observed directly and is not easy to measure quantitatively [10]. The population in this study were all candidate for civil servants basic training participants who took part in Basic training activities at the National Institute of Public Administration Training Center in 2019. While the number of samples used in this study came from the use of the Slovin formula as follows:

$$
n=\frac{N}{\left(1+\left(N x e^{2}\right)\right)}
$$

where $\mathrm{N}$ is the number of population, $\mathrm{n}$ is the number of samples, and e is the set error rate (margin error).

Until this research was conducted, the number of Basic training candidate for civils servans participants who had carried out academic evaluations and conducted actualization seminars was 280 people. Therefore, with $\mathrm{N}$ of 280 people, while the set error rate is $10 \%$, the minimum sample used is 76 people. After get sample size, sampling technique that is done is by using the technique of random sampling, the sampling technique to each participant Basic training employees to have the same opportunities to be a sample of the study. How sampling in this research is to choose the value of participant have no attendance multiples of four.

The data used in this study are primary data which has an interval scale. Collecting data in this study used an academic evaluation instrument that represented the understanding of the candidate for civil servants Basic training participants on the role and position of state civil apparatus as described in the previous section. Shile the value of the seminar actualization reports obtained through the assessment given during the conference actualization examiner who represents the working behavior of participants Basic training candidate civil servants at the workplace.

Before data collection was carried out, first the validity and reliability tests were carried out on the instruments used on 40 candidate for civil servants Basic training participants. The validity test is carried out to determine whether the instrument can be used to measure what should be measured. In this study, it means whether the academic evaluation instrument can measure the level of understanding of the role and position of civil servants who are candidate for civil servants training participants or not. To measure the level of correlation, Pearson Product Moment correlation is used with the following formula:

$$
r_{x y}=\frac{n \sum X Y-\left(\sum X\right)\left(\sum Y\right)}{\sqrt{\left\{n \sum X^{2}-\left(\sum X\right)^{2}\right\}\left\{n \sum Y^{2}-\left(\sum Y\right)^{2}\right\}}}
$$

The test criterion is if the correlation between the item score and the total score is above 0.3 then the instrument item is valid, and vice versa if the correlation value is below 0.3 it can be concluded that the instrument item is invalid so it must be corrected or must be discarded. Meanwhile, the reliability test was carried out to determine whether the instrument used several times to measure the same object would produce the same data or not. In this case, are the academic evaluation instruments reliable enough when used at different times. The instrument reliability test was carried out using internal consistency with the Beah Dua technique (split half) which was analyzed using the Spearman Brown formula as follows:

$$
r_{k k}=\frac{2\left(r_{11}\right)}{\left[1+r_{11}\right]}
$$

For the purposes of this reliability test, the instrument items are divided into two groups, namely the odd instrument group and the even instrument group. Furthermore, the data score of each group is compiled independently. An instrument is declared reliable if its reliability coefficient is at least 0.6 [11].

Good data on the level of understanding and behavior of participants Basic training employees working Basic training participants are categorized into five categories, namely $\mathrm{s}$ discussion is satisfactory (with a score of 90.01 to 100); satisfactory (with a score of 80.01 - 90.0); quite satisfactory (with a score of $70.01-80.0$ ); less satisfactory (with a score of 60.01 - 70.0); and unsatisfactory (with a score below 60.0). Processing data is done with the help of the excel program.

While the data analysis technique was performed using the Chi Square Test. This test is used to test the relationship or influence between the variable level of understanding of the candidate for civil servants Basic training participants with the work behavior variables of the candidate for civil servants Basic training participants. The steps in conducting the test using the Chi Square Test follow the five steps as follows:

1) Establish the null hypothesis and the alternative hypothesis: Ho: $\chi=0$, there is no significant influence between understanding the role and position of state civil apparatus on the work behavior of candidate for civil servans basic training graduates.

Ho: $\chi \neq 0$ there is a significant influence between understanding the role and position of state civil apparatus on the work behavior of candidate for civil servants basic training graduates.

2) Entering data into the Contingency Table between the variable understanding the role and position of state civil apparatus with work behavior variables. This data is referred to as the zero frequency $\left(f_{0}\right)$ : 
TABLE I. CONTINGENCY TABLE UNDERSTANDING THE ROLE AND POSITION OF STATE CIVIL APPARATUS WITH WORK BEHAVIOR FOR F 0

\begin{tabular}{|l|l|l|l|l|l|l|}
\hline $\begin{array}{c}\text { Understanding } \\
\text { the role and } \\
\text { position of } \\
\text { state civil } \\
\text { apparatus }\end{array}$ & $\boldsymbol{B C}$ & $\boldsymbol{M}$ & $\boldsymbol{C M}$ & $\boldsymbol{K M}$ & $\boldsymbol{T M}$ & \multirow{T}{*}{ TOTAL } \\
\cline { 2 - 7 } & & & & & \\
\hline $\mathrm{BC}$ & $\mathrm{f}_{0}$ & $\mathrm{f}_{0}$ & $\mathrm{f}_{0}$ & $\mathrm{f}_{0}$ & $\mathrm{f}_{0}$ & $\sum \mathrm{f}_{0}$ \\
\hline M & $\mathrm{f}_{0}$ & $\mathrm{f}_{0}$ & $\mathrm{f}_{0}$ & $\mathrm{f}_{0}$ & $\mathrm{f}_{0}$ & $\sum \mathrm{f}_{0}$ \\
\hline CM & $\mathrm{f}_{0}$ & $\mathrm{f}_{0}$ & $\mathrm{f}_{0}$ & $\mathrm{f}_{0}$ & $\mathrm{f}_{0}$ & $\sum \mathrm{f}_{0}$ \\
\hline KM & $\mathrm{f}_{0}$ & $\mathrm{f}_{0}$ & $\mathrm{f}_{0}$ & $\mathrm{f}_{0}$ & $\mathrm{f}_{0}$ & $\sum \mathrm{f}_{0}$ \\
\hline TM & $\mathrm{f}_{0}$ & $\mathrm{f}_{0}$ & $\mathrm{f}_{0}$ & $\mathrm{f}_{0}$ & $\mathrm{f}_{0}$ & $\sum \mathrm{f}_{0}$ \\
\hline TOTAL & $\sum \mathrm{f}_{0}$ & $\sum \mathrm{f}_{0}$ & $\sum \mathrm{f}_{0}$ & $\sum \mathrm{f}_{0}$ & $\sum \mathrm{f}_{0}$ & \\
\hline
\end{tabular}

3) Determine the expected frequency values $\left(f_{e}\right)$ with the following formula:

$$
f_{e}=\frac{(\text { Total Rows)(Total Column) }}{\text { All Total. }}
$$

The expected frequency $\left(\mathrm{f}_{\mathrm{e}}\right)$ is entered into the contingency table as follows.

TABLE II. CONTINGENCY TABLE UNDERSTANDING THE ROLE AND POSITION OF STATE CIVIL APPARATUS WITH WORK BEHAVIOR FOR F AND F $_{\mathrm{E}}$

\begin{tabular}{|c|c|c|c|c|c|c|c|c|c|c|c|c|}
\hline \multirow{2}{*}{$\begin{array}{c}\text { Understanding } \\
\text { the basic } \\
\text { values of state } \\
\text { civil apparatus }\end{array}$} & \multicolumn{10}{|c|}{ Work Behavior } & \multirow{2}{*}{\multicolumn{2}{|c|}{ TOTAL }} \\
\hline & \multicolumn{2}{|c|}{$S M$} & \multicolumn{2}{|r|}{$M$} & \multicolumn{2}{|c|}{$C M$} & \multicolumn{2}{|c|}{$\boldsymbol{K M}$} & \multicolumn{2}{|c|}{$T M$} & & \\
\hline $\mathrm{BC}$ & $\mathrm{f}_{0}$ & $\mathrm{fe}$ & $\mathrm{f}_{0}$ & $\mathrm{Fe}$ & $\mathrm{f}_{0}$ & $\mathrm{fe}$ & $\mathrm{f}_{0}$ & $\mathrm{fe}$ & $\mathrm{f}_{0}$ & $\mathrm{fe}$ & $\sum \mathrm{f}_{0}$ & $\sum \mathrm{f}_{\mathrm{e}}$ \\
\hline $\mathrm{M}$ & $\mathrm{f}_{0}$ & $\mathrm{fe}$ & $\mathrm{f}_{0}$ & $\mathrm{Fe}$ & $\mathrm{f}_{0}$ & $\mathrm{fe}$ & $\mathrm{f}_{0}$ & fe & $\mathrm{f}_{0}$ & $\mathrm{fe}$ & $\sum \mathrm{f}_{0}$ & $\sum \mathrm{f}_{\mathrm{e}}$ \\
\hline $\mathrm{CM}$ & $\mathrm{f}_{0}$ & $\mathrm{fe}$ & $\mathrm{f}_{0}$ & $\mathrm{Fe}$ & $\mathrm{f}_{0}$ & fe & $\mathrm{f}_{0}$ & $\mathrm{fe}$ & $\mathrm{f}_{0}$ & $\mathrm{fe}$ & $\sum \mathrm{f}_{0}$ & $\sum \mathrm{f}_{\mathrm{e}}$ \\
\hline KM & $\mathrm{f}_{0}$ & $\mathrm{fe}$ & $\mathrm{f}_{0}$ & $\mathrm{Fe}$ & $\mathrm{f}_{0}$ & $\mathrm{fe}$ & $\mathrm{f}_{0}$ & fe & $\mathrm{f}_{0}$ & $\mathrm{fe}$ & $\sum \mathrm{f}_{0}$ & $\sum \mathrm{f}_{\mathrm{e}}$ \\
\hline TM & $\mathrm{f}_{0}$ & $\mathrm{fe}$ & $\mathrm{f}_{0}$ & $\mathrm{Fe}$ & $\mathrm{f}_{0}$ & $\mathrm{fe}$ & $\mathrm{f}_{0}$ & $\mathrm{fe}$ & $\mathrm{f}_{0}$ & $\mathrm{fe}$ & $\sum \mathrm{f}_{0}$ & $\sum \mathrm{f}_{\mathrm{e}}$ \\
\hline TOTAL & $\sum \mathrm{f}_{\mathrm{c}}$ & & & $\overline{\sum \mathrm{f}_{\mathrm{e}}}$ & $\mathrm{Ef}$ & $\sum \mathrm{f}$ & $\mathrm{ff}$ & 1 & 11 & $\sum \mathrm{f}_{\mathrm{c}}$ & & \\
\hline
\end{tabular}

4) Calculating the value of Chi Square $\left(\chi^{2}\right.$ count $)$

$$
\chi^{2}=\left\lceil\frac{\sum\left(f_{0}-f_{e}\right)^{2}}{f_{e}}\right\rceil
$$

Determine the test criteria, with the following criteria:

If $\chi^{2}$ count $\leq \chi^{2}$ table then $\mathrm{H}_{0}$ is accepted

If $\chi^{2}$ count $>\chi^{2}$ table then $\mathrm{H}_{0}$ is rejected

5) Specifies the value of $\chi^{2}$ table: With a significance level (margin of error) $\alpha=10 \%$.

Degrees of freedom (degree of freedom) $\mathrm{df}=($ row 1$)$ (column 1).

6) Compares $\chi^{2}$ count with $\chi^{2}$ table and makes a conclusion: If $\chi^{2}$ count $\leq \chi^{2}$ table then $\mathrm{H}_{0}$ is accepted, it means that there is no significant influence between understanding the role and position of state civil apparatus on the work behavior of candidate for civil servants basic training participants.

If $\chi_{\text {count }}^{2}>\chi^{2}$ table then $\mathrm{H}_{0}$ is rejected, it means that there is a significant influence between understanding the role and position of state civil apparatus on the work behavior of the candidate for civil servants basic training participants.

\section{RESULTS AND DISCUSSION}

\section{A. Validity Test}

The academic evaluation instrument that shows understanding of the role and position of state civil apparatus consists of 80 question items. Testing the validity of each item used item analysis, which is to correlate the score of each item with the total score which is the number of each item score. The following table shows the results of the correlation analysis between the score for each item and the total score.

TABLE III. ANALYSIS RESULTS OF INSTRUMENT ITEMS UNDERSTANDING

\begin{tabular}{|c|c|c|c|c|c|}
\hline $\begin{array}{c}\text { No. } \\
\text { Instru- } \\
\text { ment } \\
\text { Items }\end{array}$ & $\begin{array}{c}\text { Correlation } \\
\text { coefficient }\end{array}$ & $\begin{array}{l}\text { Infor- } \\
\text { mation }\end{array}$ & $\begin{array}{c}\text { No. } \\
\text { Instru- } \\
\text { ment } \\
\text { Items }\end{array}$ & $\begin{array}{c}\text { Correlation } \\
\text { coefficient }\end{array}$ & $\begin{array}{l}\text { Infor- } \\
\text { mation }\end{array}$ \\
\hline 1 & 0.71 & Valid & 41 & 0.57 & Valid \\
\hline 2 & 0.63 & Valid & 42 & 0.45 & Valid \\
\hline 3 & 0.51 & Valid & 43 & 0.86 & Valid \\
\hline 4 & 0.45 & Valid & 44 & 0.56 & Valid \\
\hline 5 & 0.60 & Valid & 45 & 0.39 & Valid \\
\hline 6 & 0.59 & Valid & 46 & 0.56 & Valid \\
\hline 7 & 0.79 & Valid & 47 & 0.53 & Valid \\
\hline 8 & 0.72 & Valid & 48 & 0.57 & Valid \\
\hline 9 & 0.45 & Valid & 49 & 0.45 & Valid \\
\hline 10 & 0.45 & Valid & 50 & 0.86 & Valid \\
\hline 11 & 0.56 & Valid & 51 & 0.70 & Valid \\
\hline 12 & 0.39 & Valid & 52 & 0.86 & Valid \\
\hline 13 & 0.41 & Valid & 53 & 0.70 & Valid \\
\hline 14 & 0.67 & Valid & 54 & 0.79 & Valid \\
\hline 15 & 0.35 & Valid & 55 & 0.72 & Valid \\
\hline 16 & 0.46 & Valid & 56 & 0.45 & Valid \\
\hline 17 & 0.67 & Valid & 57 & 0.45 & Valid \\
\hline 18 & 0.75 & Valid & 58 & 0.56 & Valid \\
\hline 19 & 0.63 & Valid & 59 & 0.39 & Valid \\
\hline 20 & 0.57 & Valid & 60 & 0.41 & Valid \\
\hline 21 & 0.45 & Valid & 61 & 0.67 & Valid \\
\hline 22 & 0.86 & Valid & 62 & 0.79 & Valid \\
\hline 23 & 0.70 & Valid & 63 & 0.72 & Valid \\
\hline 24 & 0.56 & Valid & 64 & 0.45 & Valid \\
\hline 25 & 0.53 & Valid & 65 & 0.45 & Valid \\
\hline 26 & 0.47 & Valid & 66 & 0.55 & Valid \\
\hline 27 & 0.57 & Valid & 67 & 0.67 & Valid \\
\hline 28 & 0.63 & Valid & 68 & 0.75 & Valid \\
\hline 29 & 0.79 & Valid & 69 & 0.63 & Valid \\
\hline 30 & 0.64 & Valid & 70 & 0.57 & Valid \\
\hline 31 & 0.58 & Valid & 71 & 0.45 & Valid \\
\hline 32 & 0.66 & Valid & 72 & 0.57 & Valid \\
\hline 33 & 0.45 & Valid & 73 & 0.45 & Valid \\
\hline 34 & 0.74 & Valid & 74 & 0.86 & Valid \\
\hline 35 & 0.53 & Valid & 75 & 0.70 & Valid \\
\hline
\end{tabular}
THE ROLE AND POSITION OF STATE CIVIL APPARATUS 
Table 3. Cont.

\begin{tabular}{|l|l|l|l|l|l|}
\hline 36 & 0.53 & Valid & 76 & 0.56 & Valid \\
\hline 37 & 0.62 & Valid & 77 & 0.53 & Valid \\
\hline 38 & 0.35 & Valid & 78 & 0.67 & Valid \\
\hline 39 & 0.64 & Valid & 79 & 0.75 & Valid \\
\hline 40 & 0.73 & Valid & 80 & 0.63 & Valid \\
\hline
\end{tabular}

Based on the results of the Pearson product moment correlation between the score of each of brackish $g$ grains with a total score, correlation values above 0.30 . This shows that the academic evaluation instrument is valid.

\section{B. Reliability Test}

For the purposes of this reliability test, the instrument items are divided into two groups, namely the odd instrument group and the even instrument group. The correlation coefficient between the total score of the odd instrument group and the even instrument group total score is 0.68. This correlation coefficient is then entered into the Spearman Brown formula as follows:

$$
r_{k k}=\frac{2\left(r_{11}\right)}{\left[1+r_{11}\right]}=\frac{2 *(0,68)}{[1+0,68]}=0,81
$$

The reliability obtained for the academic evaluation instrument is 0.81 . This shows that this academic evaluation instrument is reliable.

\section{Chi Square test}

Based on the results of the data processing that has been carried out, it shows that the variable understanding the role and position of state civil apparatus has a minimum value of 67.48 and a maximum value of 89.05 . While the average of this variable is 80.60 with a standard deviation of 4.23 . The work behavior variable has a minimum value of 77.83 and a maximum value of 97.50 . While the average of this variable is 87.40 with a standard deviation of 3.90 .

The stages in carrying out testing using the Chi Square Test are as follows:

1) Establish the null hypothesis and the alternative hypothesis: Ho: $\chi=0$, there is no significant influence between understanding the role and position of state civil apparatus on the work behavior of candidate for civil servants basic training graduates.

Ho: $\chi \neq 0$ there is a significant influence between understanding the role and position of state civil apparatus on the work behavior of candidate for civil servants basic training graduates.
2) The contingency table obtained is as follows:

TABLE IV. CONTINGENCY TABLE UNDERSTANDING THE ROLE AND POSITION OF STATE CIVIL APPARATUS WITH WORK BEHAVIOR FOR F

\begin{tabular}{|c|c|c|c|c|c|c|}
\hline \multirow{2}{*}{$\begin{array}{c}\text { Academic } \\
\text { Evaluation }\end{array}$} & \multicolumn{5}{|c|}{ Actualization Value } & \multirow[b]{2}{*}{ TOTAL } \\
\hline & $B C$ & $M$ & $C M$ & $K M$ & $T M$ & \\
\hline $\mathrm{BC}$ & 0 & 0 & 0 & 0 & 0 & 0 \\
\hline $\mathrm{M}$ & 13 & 30 & 2 & 0 & 0 & 45 \\
\hline $\mathrm{CM}$ & 9 & 20 & 0 & 0 & 0 & 29 \\
\hline KM & 0 & 1 & 1 & 0 & 0 & 2 \\
\hline TM & 0 & 0 & 0 & 0 & 0 & 0 \\
\hline TOTAL & 22 & 51 & 3 & 0 & 0 & 76 \\
\hline
\end{tabular}

3) The expected frequency values $\left(f_{e}\right)$ are as follows:

$$
f_{e}=\frac{(\text { Total Rows)(Total Column) }}{\text { All Total. }}
$$

TABLE V. CONTINGENCY TABLE UNDERSTANDING THE ROLE AND POSITION OF STATE CIVIL APPARATUS WITH WORK BEHAVIOR FOR F $F_{0}$ AND F $_{\mathrm{E}}$

\begin{tabular}{|l|l|l|l|l|l|l|l|l|}
\hline \multirow{2}{*}{$\begin{array}{c}\text { Academic } \\
\text { Evaluation }\end{array}$} & \multicolumn{7}{|c|}{ Actualization Value } & \multicolumn{2}{|c|}{ TOTAL } \\
\cline { 2 - 10 }$n$ & $\boldsymbol{B C}$ & & $\boldsymbol{M}$ & & $\boldsymbol{C M}$ & & & \\
\hline M & 13 & 13.03 & 30 & 30.20 & 2 & 1.78 & 45 & 45 \\
\hline CM & 9 & 8.39 & 20 & 19.46 & 0 & 1.14 & 29 & 29 \\
\hline KM & 0 & 0.58 & 1 & 1.34 & 1 & 0.08 & 2 & 2 \\
\hline TOTAL & 22 & 22 & 51 & 51 & 3 & 3 & 76 & 76 \\
\hline
\end{tabular}

4) Calculating the value of Chi Square $\left(\chi^{2}\right.$ count $)$ :

$$
\begin{gathered}
\chi^{2}=\left\lceil\frac{\sum\left(f_{0}-f_{e}\right)^{2}}{f_{e}}\right\rceil \\
\chi^{2}=\left[\frac{(13-13,03)^{2}}{13,03}\right]+\left[\frac{(30-30,20)^{2}}{30,20}\right]+\left[\frac{(2-1,78)^{2}}{1,78}\right]+ \\
{\left[\frac{(9-8,39)^{2}}{8,39}\right]+\left[\frac{(20-19,46)^{2}}{--0,58)^{2}}\right]+\left[\frac{(0-1,14)^{2}}{1,14}\right]} \\
+\left[\frac{(0-0,58,34)^{2}}{1,34}\right]+\left[\frac{(1-0,08)^{2}}{0,08}\right] \\
\chi^{2}=11,45
\end{gathered}
$$

5) Determine test criteria:

If $\chi^{2}$ count $\leq \chi^{2}$ table then $\mathrm{H}_{0}$ is accepted

If $\chi^{2}$ count $>\chi^{2}$ table then $\mathrm{H}_{0}$ is rejected

6) Specifies the value of $\chi^{2}$ table:

With a significance level ( margin of error ) $\alpha=10 \%$.

Degrees of freedom ( degree of freedom $) \mathrm{df}=($ row 1$)$ (column 1).

Df $=(3-1)(3-1)=4$

$\chi^{2}$ table is 7,78 


$$
\begin{aligned}
& \text { 7) Comparing } \chi_{\text {count }}^{2} \text { with } \chi^{2} \text { table: } \\
& \chi_{\text {count }}^{2}=11,45 \\
& \chi_{\text {table }}^{2}=7,78
\end{aligned}
$$

Based on these results, it can be concluded that $\chi^{2}$ count $=$ 11.45 is greater than $\chi^{2}$ table $=7.78$, thus $\mathrm{H}_{0}$ which states that there is no significant influence between understanding the role and position of state civil apparatus on the work behavior of candidate for civil servants basic training graduates rejected. This means that understanding the role and position of state civil apparatus has changed the work behavior of candidate for civil servants basic training graduates. This is in accordance with the theory that the mindset can change a person's attitude and behavior.

\section{Discussion}

Based on the results of the tests that have been carried out, it was found that the understanding of the role and position of state civil apparatus obtained by candidate for civil servants Basic training participants can be transformed into expected work behavior in accordance with the results of basic candidate for civil servants training. This is in accordance with the theory used that the mindset that is built through the candidate for civil servants Basic Training activities can change the attitude and work behavior of the graduates.

When contextualized on the activities of candidate for civil servants Basic training, the agenda of the roles and positions of civil servants equips participants with the values of the roles and positions needed in carrying out civil servant duties professionally as public servants which include the ability to prioritize services, uphold whole of governance, improve the quality of task implementation through work management as a civil servant, and prioritizing basic values as a civil servant. The agenda for the role and position of civil servants which includes whole of governance, public services, and state civil apparatus management can be transformed into positive attitudes and behaviors for graduates of candidate for civil servants Basic training participants.

\section{CONCLUSION}

Based on the results of data analysis and discussion, several things can be concluded as follows:

- Characteristics of candidate for civil servants Basic training participants based on the understanding of the role and position of state civil apparatus, it was found that the majority had satisfactory understanding, namely as many as 45 people or $59 \%$.

- Characteristics of candidate for civil servants Basic training participants based on work behavior found that the majority had satisfying behavior, namely 51 people or $67 \%$.

- There is a significant relationship between understanding the role and position of state civil apparatus with the work behavior of Basic training candidate for civil servants graduates. This is indicated by the acquisition of a significance value from the relationship of $\chi^{2}$ count $=1.45$.

Based on the above conclusions, the researcher proposes the following suggestions:

- With regard to the understanding model of the role and position of state civil apparatus and the work behavior of Basic training candidate for civil servants graduates, understanding the role and position of state civil apparatus is an important variable affecting the work behavior of Basic training candidate for civil servants graduates. For this reason, understanding of the role and position of state civil apparatus can be improved.

- The researcher realizes that this study is full of limitations. This limitation is related to several things such as the concept, methodology and technical research. The conceptual limitation of this study lies in the very simple model testing.

- The next limitation is the use of a quantitative method approach in this study. Using statistical tools to analyze quantifiable qualitative variables, the results of this study will be fraught with weaknesses.

- This methodical approach cannot dig deep information for each variable under study. Sometimes statistical techniques use many simplifications, which can lead to a lack of thoroughness in this study.

- There are limitations to this study, expected in the next research that can be developed using the concept, methodology and technical implementation of research in order to better study produced more efficient.

\section{REFERENCES}

[1] J.W. Bloom, Systems Thinking, Pattern Thinking, and Abductive Thinking as the Key Elements of Complexs Learning. In the annual meeting of the American Educational Research Association. Northern Arizona University, 2010.

[2] C. Satria, You Are What You Think You Are What You Believe. Yogyakarta: Shira Media, 2015.

[3] I. Wiseful, Action Power. Jakarta: PT Elex Media Komputindo, 2013.

[4] J. Nainggolan, Personal Success Cockpit. Jakarta: PT Gramedia. n.d.

[5] M. Anas, Psychology Towards Educational Applications. Bandung: Pustaka Education, 2011

[6] R. Hadisubrata, Success Through The original You. Jakarta: PT Elex Media Komputindo, 2012.

[7] N. Muhajir, Metodologi Penelitian. Yogyakarta: Rake Sarasin, 1992.

[8] A. Ahmadi, Psikologo Pendidikan. Jakarta: Rineka Cipta, 2004.

[9] State Administration Agency Regulation No. 12 of 2018 concerning Basic Training for Prospective Civil Servants, 2018.

[10] M. Montessori, "The Mindset of High School Teachers About Its Role in Teaching Citizenship Education”. Educational Forum, 31 (1), 1-12. 2006.

[11] Sugiyono, Educational Research Methods (Quantitative Approaches, Qualitative and R \& D). Bandung: Alfabeta, 2015. 